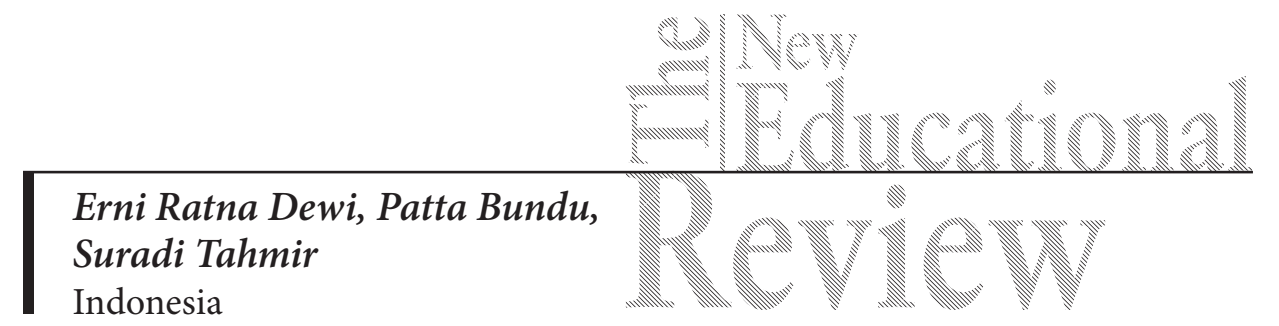

\title{
The Effect of Emotional Intelligence, Competence and Interpersonal Communication on the Performance of Senior High School Teachers Through Achievement Motivation in Makassar, Indonesia
}

DOI: 10.15804/tner.2016.44.2.14

\begin{abstract}
The presented research aims at analyzing whether the emotional intelligence, competence, and interpersonal communication directly affect teacher performance in senior high schools in Makassar. This research also aims at analyzing whether emotional intelligence, competence, and interpersonal communication indirectly affect teacher performance through achievement motivation in senior high schools in Makassar. The research was a quantitative study. The sample of this research consisted of 130 respondents. The data were analyzed using Structural Equation Model AMOS 18. The findings show that emotional intelligence has a positive and significant effect on teacher performance. Every teacher's emotional intelligence proves convenient in teaching. Competence has a positive and significant effect on teacher performance. It is important in supporting the teaching profession. In addition, it allows teachers to conduct the learning process effectively.
\end{abstract}

Keywords: emotional intelligence, competence, interpersonal communication, achievement motivation, performance

\section{Introduction}

The phenomenon of the performance of senior high school teachers in Makassar is decreased. The teacher performance on the results of the learning process carried out in the field studies showed that the performance is decreased based on 
the percentage of student achievement and the teacher's ability, either the certified or non-certified teachers. The evaluations of teacher performance are determined in accordance with the teacher's ability to plan and make preparations, master the material, control methods, manage and evaluate students.

The decrease in teacher performance in the last five years has shown that the percentage was below $3 \%$ both in general subject teachers, science teachers, social studies teachers, and linguistics teachers. The decrease indicates that efforts to improve and enhance the performance of teachers are still lacking (Department of Education in Makassar, 2015).

This decrease indicates that student achievement is also decreased because the teacher's performance is still low. Therefore, the teacher's performance needs to be improved in the planning and preparation, such as preparing lesson plans, mastering of the material, mastering of the teaching methods, managing students and evaluating students (Farida, 2014: 12).

The percentage of formative and summative assessment for teacher performance shows that the average of teacher performance for general subject teachers reaches $79.6 \%$. The average of natural science teachers is $72.08 \%$. The average of social science teachers is $82.62 \%$. The average of linguistics teachers is $78.74 \%$. The supporting data indicate that the teacher's performance becomes a concern in the learning process because the teacher performance that is decreased results in student underachievement (Department of Education in Makassar, 2015).

This matter can be considered to improve teacher performance by applying the teacher performance appraisal proposed by Friedrich (2013: 96). There are several indicators of teacher performance evaluation. The first is the ability to plan and make preparations for teaching. The second is the mastering of the material being taught to students. The third is the mastering of methods and teaching strategies. The fourth is giving assignments to students. The fifth is the ability to manage students. The sixth is the ability to conduct appraisals and evaluation.

A decrease in teacher performance can be caused by a variety of issues related to achievement motivation that is not fulfilled, emotional intelligence, competence and interpersonal communication. According to Queen (2010: 87), teacher performance will increase if teachers achieve the appropriate achievement motivation based on emotional intelligence and can develop excellent interpersonal communication.

A decrease in teacher performance occurs because achievement motivation is not optimal. That shows that teachers do not have the encouragement for achievement based on self-assessment and judgment of others. It is because teachers have less incentive to meet the needs towards the achievement of the goals. Farida 
(2014: 12) argues that it is hard for teachers to improve their performance if their motivation is low. There are several causes of low motivation. First, the need to be achieved is not met. Second, the need for the desired power is not fulfilled. Third, the need for affiliation is not met.

The achievement motivation theory proposed by McClelland is also known as Three Needs Theory: the need for achievement, the need for power and the need for affiliation. Teachers' needs for achievement motivation are crucial in realizing the attainment of performance. Therefore, teachers' success in performance can be enhanced by meeting the needs for achievement motivation (Farida, 2014: 15).

The results of observations made by researchers in observing senior high school teachers in Makassar show that teachers' low achievement motivation and low performance are directly and indirectly affected by the level of emotional intelligence, competence, and interpersonal communication, which is less actualized by teachers in performing their duties and functions in the process of teaching and learning in schools.

According to Giselle (2009: 71), emotional intelligence has a direct positive and significant influence on achievement motivation and performance. Robert (2010: 64) states that competence simultaneously and significantly affects achievement motivation and performance. Kelly (2014: 115) states that interpersonal communication simultaneously and significantly affects performance through achievement motivation. Osvaldo (2011: 82) states that achievement motivation positively and significantly affects performance. Gieselle (2009: 89) and Queenn (2010:116) state that emotional intelligence and interpersonal communication simultaneously and significantly affect performance through achievement motivation. Robert (2010: 70), Gieselle (2009: 90) and Osvaldo (2011: 83) state that achievement motivation and performance are influenced positively and significantly by emotional intelligence, competence, and interpersonal communication.

The results of this study assert that emotional intelligence affects teacher performance through achievement motivation. It can be seen that there is a different effect between the teachers who have emotional intelligence including self-awareness, self-regulation, self-encouragement, empathy and skills and the teachers who do not have the intelligence aspects in the teaching and learning activities. The teachers who have emotional intelligence in the teaching and learning process will efficiently realize their performance through achievement motivation, whereas the teachers who lack emotional intelligence showed that they have low performance through achievement motivation.

Goleman (2012: 5) put forward the theory of EQ (emotional quotient). He states that emotional intelligence is the quality of a person's emotional intelligent 
in understanding self-consciousness, having an ability to organize, motivate themselves, and having empathy and skills. Managers of human resources widely use this theory in order to improve performance through achievement motivation. Startdman (2011:49) states that through emotional intelligence conducted by the organization, human resource performance improvement can be realized through the fulfillment of achievement motivation.

It is undeniable that the competence is one of the factors which directly affect customer satisfaction and teacher performance. The teachers who have a high level of competence in teaching and the teachers who have a low level of competence can be compared based on the aspect of pedagogical, professional, personal and social interaction in performing the duties and functions in teaching. The teachers who have a high level of competence find it easy to improve performance through the fulfillment of achievement motivation, while the teachers who have a low level of competence, demonstrate unsatisfactory performance.

Janawi (2012: 7) claims that competence is the potential of a person to perform work activities. The competence in relation to the competence of the teacher is teaching in the pedagogical, professional, personal and social aspects. It corresponds to the assessment of competence according to Law Number 14 of 2005 regarding Teachers and Lecturers.

Realizing the achievement motivation and performance of teachers is not only seen from the personal aspects of the teacher, but also from the aspect of interpersonal communication. Interpersonal communication applied by senior high school teachers in Makassar has not been optimal. It is because there is a gap between teachers in communication. They have not applied interpersonal communication in teaching and learning activities.

Improving teacher interpersonal communication can be conducted by applying the theory of interpersonal communication. Devito (2007:252) states that interpersonal communication is the process of sending and receiving between two people or among a small group of people, with some effect and some immediate feedback. Devito believes that the process of interpersonal communication is executed based on five aspects, namely openness, a positive attitude, equity, empathy, and support.

The description of the phenomenon, which is supported by data and facts, becomes a consideration for conducting research under the title "The Effect of Emotional Intelligence, Competence and Interpersonal Communication on the Performance of Senior High School Teachers through Achievement Motivation in Makassar". 


\section{Research Problem}

Referring to the description above, the problems of this research were formulated as follows:

1. Do emotional intelligence, competence, and interpersonal communication affect the performance of senior high school teachers in Makassar?

2. Do emotional intelligence, competence, and interpersonal communication affect teacher performance through achievement motivation of senior high school teachers in Makassar?

\section{Method}

The research was a quantitative descriptive study. It was designed to address problems that had been formulated and the goals to be achieved. The populations in this study were all the teachers of science and math in senior high school in Makassar, as many as 368 teachers. The study used three types of schools based on the number of classes in each senior high school in Makassar. The researchers used purposive sampling techniques based on the types of the school by observing mathematics teachers and natural sciences teachers based on the situation of the senior high school in Makassar. The sampling in this study was conducted at two stages. The first stage was determining the number of schools in each type (type $\mathrm{A}, \mathrm{B}$, and C), and the researchers only took $35 \%$ of each type of school. The second stage was taking some of the schools selected to be the subject of research for science and math teachers for each type of school.

The researchers specified the number of samples in the investigation. The sample included 130 science and math teachers with the following details.

The data were collected through observation and questionnaires. The validity of data to find out the feasibility of indicator variables was through validity and reliability. Data were then analyzed to explain the phenomenon in this study by using descriptive statistical analysis techniques and inferential analysis using Structural Equation Modeling (SEM).

\section{Results and Discussion}

After the assumption testing and the necessary action toward an error were performed, the fit of a statistical model was made according to the criteria for fitness 
model, such as GFI (Goodness of fit index), adjusted GFI (AGFI), Tucker Lewis Index (TLI), CFI (Comparative of fit index), and RMSEA (Root Mean Square Error of Approximation), either for an individual model or complete model. The results of the measurements of the dimensions or variable indicators can form latent variables and confirmatory factor analysis, respectively.

The results of the measurement of the model showed that the model is not fit. It means that there is still a mismatch between data and models. From the eight criteria, no criterion is met. It shows that the level of reception is not good. Therefore, it should be further analyzed.

Furthermore, to determine the variables that can be used as an indicator of teacher performance, it can be observed based on the value of regression and the significance level $\left(p^{* * *}\right)$. It means that the probability value of $<0.05$ or 0.000 reflects each of the variables as indicators of teacher performance. Details are shown in Table 1 .

Table 1. Regression value for the measurement of exogenous factors toward endogenous

\begin{tabular}{lccccl}
\hline Variables & $\begin{array}{c}\text { Estima- } \\
\text { tion }\end{array}$ & $\begin{array}{c}\text { Standard } \\
\text { of Error }\end{array}$ & $\begin{array}{c}\text { Critical } \\
\text { Ratio }\end{array}$ & $\begin{array}{c}\text { Probability } \\
(\mathrm{p})\end{array}$ & Explanation \\
\hline $\mathrm{Y} 1 \leftarrow \mathrm{X} 1$ & 0.545 & 0.107 & 5.118 & 0.000 & Significant \\
\hline $\mathrm{Y} 1 \leftarrow \mathrm{X} 2$ & 0.962 & 0.337 & 2.855 & 0.004 & Significant \\
\hline $\mathrm{Y} 1 \leftarrow \mathrm{X} 3$ & -0.352 & 0.328 & -1.072 & 0.284 & Not significant \\
\hline $\mathrm{Y} 2 \leftarrow \mathrm{X} 1$ & -0.021 & 0.166 & -0.129 & 0.897 & Not significant \\
\hline $\mathrm{Y} 2 \leftarrow \mathrm{X} 2$ & 0.384 & 0.471 & 0.814 & 0.415 & Not significant \\
\hline $\mathrm{Y} 2 \leftarrow \mathrm{X} 3$ & 0.611 & 0.469 & 1.304 & 0.192 & Not significant \\
\hline $\mathrm{Y} 2 \leftarrow \mathrm{Y} 1$ & 0.606 & 0.172 & 3.529 & 0.000 & Significant \\
\hline
\end{tabular}

Based on the loading factor, which is viewed by the critical ratio of SEM analysis results, emotional intelligence (X1) has a significant and positive effect on achievement motivation (Y1), with a significant level of 0.000 . Competence (X2) has a significant and positive effect on achievement motivation (Y1), with a significant level of 0.004. Interpersonal communication (X3) has a negative and insignificant effect on achievement motivation (Y1), with a significant level 
of 0.284. Emotional intelligence (X1) has a negative and insignificant effect on teacher performance (Y2), with a significant level of 0.897. Competence (X2) has a positive and insignificant effect on teacher performance (Y2), with a significant level of 0.415. Interpersonal communication (X3) has a positive and insignificant effect on teacher performance (Y2), with a significant level of 0.415. Achievement motivation (Y1) has a positive and significant effect on teacher performance (Y2), with a significant level of 0.4150 .000 .

\section{Conclusion and Suggestion}

Based on the results of analysis and the above discussion, the following conclusions can be drawn. First, emotional intelligence has a positive and significant effect on teacher performance. Second, competence has a positive and significant effect on teacher performance. Third, interpersonal communication does not affect teacher performance. Fourth, emotional intelligence does not affect teacher performance through achievement motivation. Fifth, competence does not affect teacher performance through achievement motivation. Sixth, interpersonal communication does not affect teacher performance through achievement motivation.

Based on the above conclusions, the following suggestions can be made. First, schools, especially senior high school in Makassar, need to pay attention to the importance of teachers, so that education could be run effectively. Second, to improve education in school, every teacher should be able to provide quality education. Third, education and teaching activities should become local wisdom for an educated nation by enhancing the professional role of teachers as unsung heroes in the world of education. Fourth, this research can be a scientific study that can be compared with some of the research that is relevant and specific to the variables that are studied.

\section{References}

Anak Agung, S. (2008). The Influence of Work Ability, Discipline, Interpersonal Communication on the Performance through Achievement Motivation of Senior High School Teachers in the Province of West Java.

Baitunissa (2011). Competence and Emotional Quotient toward Motivation and Performance by Teacher in Malaysia.

Callisto, M. (2013). Competence, Emotional Quotient and Organization Communication toward Increasing of Performance and Motivation by Teacher di Michigan America. 
Darwin, R. (2013). Are Employee Motivation, Interpersonal Communication and Basic Competence Inter-Related: Evidence from Banking Sector of Pakistan.

Devito, J.A. (2007). The Interpersonal Communication. Book Eleventh Edition. USA: Pearson Education. Inc.

Djatmiko (2014). The Effect of Competence, Communication, and Interpersonal Communication on the Teacher Performance through Achievement Motivation of Teachers.

Farida (2014). Human Resource Management: Application of Theory. Publisher: Elex Media Komputindo, Jakarta.

Friedrich, J. (2013). The Human Resource and Performance in Application of Teacher Profession. Harvard Business School Press, Boston.

Gieselle (2009). Organizational Behavior. New York, McGraw-Hill Book Company, $3^{\text {rd }}$ ed. Goleman, D., (2012). Emotional Intelligence. PT Gramedia Pustaka Utama, Jakarta.

Goleman, D., (2012). Working With Emotional Intelligence. PT Gramedia Pustaka Utama, Jakarta.

Hans Kinsley (2010). Self-Concept, Motivation and Competence in Increasing of Motivation and Performance by Teacher in Texas America.

Hawiah (2013). The Influence of Emotional Intelligence, Career Development, and Cooperation on the Performance through the Achievement Motivation of Human Resources at the Local Government in Semarang.

Janawi (2012). Competence of Teachers: The Image of a Professional Teacher. Publisher: Alfabeta, Bandung.

Kelly, M. (2014). The Interpersonal Communication. $4^{\text {th }}$ Edition. New York: Harper and Row Publisher

Liu Chen (2011). Analysis of Determinant Factors to Increasing of Satisfaction and Performance by Teacher in Hong Kong.

Mark Oneil, (2014). Affected of Competence, Emotional Intelligence and Communication toward Motivation and Performance by Teacher in High School Copenhagen.

Nisbith, J. (2011). Competence and Emotional Intelligence on Achievement Motivation and Employee Performance.

Osvaldo, R. (2011). Human Resource Management in Strength Quality Prospective. Published McGraw Hill, New York.

Queen, W. (2010). Performance Management in Organization. Revision Edition, Mas Hougton Mifflin Company, Boston.Rakhmat, Jalaluddin, 2013, Psikologi Komunikasi. Penerbit Remaja Rosdakarya, Bandung.

Robert, S. (2010). Managing Organizations, Readings and Cases. Boston, Toronto Little, Brown and Company.

Samuelson, D. (2012). Effect of Intelligence and Competence toward Performance through Motivation by Teacher on Manchester City England.

Shene, D. (2012). Emotional Question, Competence and Communication toward Motivation and Performance by Library Personnel in Academic and Research Libraries in Oyo State. Stardman, L., (2011). Education Autonomy Management. Published by McGraw Hill, Ohio. 